THE INTERNATIONAL

REVIEW OF RESEARCH IN

OPEN AND DISTANCE LEARNING

\title{
Distance Students' Readiness for Social Media and Collaboration
}

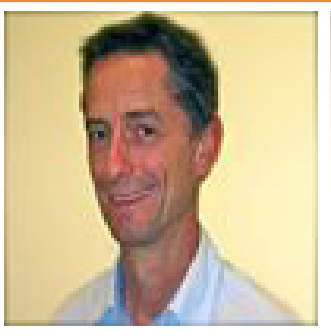

Bruno Poellhuber and Normand Roy, Université de Montreal, Canada Terry Anderson, Athabasca University, Canada

\section{Abstract}

In recent years, there has been a rapid growth in the use of social networking tools (e.g., Facebook) and social media in general, mainly for social, recreational, and entertainment purposes (Smith, Salaway, \& Caruso, 2009). Many educators believe that these tools offer new educational affordances and avenues for students to interact with each other and with their teachers or tutors. Considering the traditional dropout rate problem documented in distance courses (Rovai, 2003; Woodley, 2004), these tools may be of special interest for distance education institutions as they have the potential to assist in the critical "social integration" associated with persistence (Sweet, 1986; Tinto, 1975). However, as distance students are typically older than regular on-campus students (Bean \& Metzner, 1985; Rovai, 2003), little is known about their expertise with social media or their interest in harnessing these tools for informal learning or collaborating with peers.

To investigate these issues, an online questionnaire was distributed to students from four large Canadian distance education institutions. A systematic sampling procedure led to 3,462 completed questionnaires. The results show that students have diverse views and experiences, but they also show strong and significant age and gender differences in a variety of measures, as well as an important institution effect on the student's interest in collaboration. Males and younger students scored higher on almost all indicators (past teamwork experience, cooperative preferences, attitudes toward technology, experience with social software, etc.). These age and gender differences should be interpreted cautiously, however, as they are based on self-reported measures. The limits of the study, as well as future developments and research questions, are outlined.

Keywords: Distance education; social software; web conferencing; collaboration; social presence; technology; transparency 
In recent years, the Web has been radically transformed, shifting from an information repository to a more social environment where users are not only passive receivers or active harvesters of information, but also creators of content, or "produsers" (Bruns, 2008). Even if the term itself is contentious, "Web 2.0" is used to characterize a web environment that is moving from publishing to participation, contribution, and user-defined content creation and organization through posting, commenting, tagging, and folksonomy creation. The use of social software and social networking has been growing exponentially with applications in social, gaming, media, business, and education contexts. For example, Facebook is now the second most frequented site (just after Google) in North America (Alexa, 2011) and claims over 750 million members (Facebook, 2011).

The term social software refers to a set of network tools designed specifically to support sharing, collaborating, and socializing, resulting in the development of multiple forms of social capital (Jones \& Thomas, 2007). Though (currently) much less popular than commercial and entertainment uses and definitions, educational social software was defined in 2005 as "networked tools that support and encourage individuals to learn together while retaining individual control over their time, space, presence, activity, identity and relationship" (Anderson, 2005). Social software tools or functions include profiles, wikis, blogs, microblogging (e.g., Twitter), social bookmarking, wall posting, photo and video sharing and tagging, and calendaring, to name only a few. Social networking sites such as Elgg, Ning, and Facebook typically offer a number of these functions in a single environment.

Social software is used primarily for informal and recreational use (Smith, Salaway, \& Caruso, 2009). However, we argue that it also offers new educational affordances that can be exploited in formal learning. The educational use of wikis and blogs is increasing (Richardson, 2006). Some educational uses of Facebook are also emerging, including a large number of educational institutions having Facebook pages and "communities" of students. Dron and Anderson (2007) note that an essential characteristic of social software is that it scales well and gains strength from large numbers of users, thus making them attractive and cost-effective for use in both campus and open and online education contexts.

It has been noted that while educators have been thinking a lot about formal groups in education (e.g., classes, and structures to support collaborative learning), new types of "network" and "set-based" collaboration are also emerging (Dron, 2010; Dron \& Anderson 2007, 2009). In research using the social software platform Elgg, Garrett, Thoms, Soffer, and Ryan (2007) found that access to peer work and peer relations improved both the perception of social presence and students' motivation.

In recent years, with larger bandwidth availability to a large public, the use of real-time web conferencing software (such as Elluminate, WebX, and Adobe Connect) has also been growing. These systems use real-time audio-video communication systems to simulate classroom-based learning, and, in some ways, add functionality to go beyond classroombased learning, including diverse collaborative functions such as document sharing, whiteboard, chat, polling, and application sharing. 


\section{Problem and Conceptual Grounding}

The number of students registering in online courses in higher education is increasing steadily compared to on-campus registrations (Allen \& Seaman, 2010). But distance education (DE) and online courses suffer from higher attrition rates than campus-based offerings (Bernard et al., 2004). This phenomenon is particularly acute for the self-paced and continuous enrollment forms of distance education (Misko, 2000, 2001). Self-pacing and continuous enrollment increase flexibility for students and teachers, yet this flexibility comes at a cost of greater requirements for student motivation, self-direction, and discipline.

While persistence involves a complex set of individual, demographic, socioeconomic, and environment variables (Bourdages \& Delmotte, 2001), only learner support systems, instructional designs, and other institutional variables are controllable by the distance education institution and thus can potentially be manipulated to improve persistence rates. Most avenues explored to enhance persistence in DE courses focus on the enhancement of student support systems through individual tutoring, peer collaboration, and face-toface meetings (Gagné, Deschênes, Bourdages, Bilodeau, \& Dallaire, 2002). Web conferencing systems are increasingly used as tools to replace face-to-face meetings or to mimic the traditional class environment, with some positive impacts on persistence (Bernard et al., 2004).

Typically in distance education, and entirely in self-paced models, students remain invisible to each other-often as a result of increasing constraints on institutions when it comes to releasing personal and private information about students. Social software and web conferencing tools offer new interaction affordances as well as new forms of collaboration. In addition, with such technology, students and instructors can become more directly visible to and socially present with each other.

\section{Social Presence}

The notion that a sense of presence can be conveyed through technology has been the object of many studies in the educational and media domains. The diversity of concepts used to discuss the topic demonstrates this interest: social presence, telepresence, transactional distance, immediacy, and transactional presence. The term "social presence" has been defined in a number of significantly different ways. This term originated in the field of communication psychology and was first defined as "the degree of salience of the other person in the interaction and the consequent salience of the interpersonal relationships" (Short, Williams, \& Christie, 1976).

The theory of the richness of media is often invoked to explain the differences in the potential of various media to convey a social presence. Wealth of information is defined as a capacity for information to impact understanding within a given time frame (Daft \& Lengel, 1986). According to this theory, if a medium is very visual and highly interactive, it will provide a wealth of information and will more effectively convey a sense of social presence. Some research results indicate precisely that when given the choice, educators and learners have a preference for synchronous tools (Poellhuber, 2007), that is web videoconferencing. 
Conversely, lean media, notably text, was originally thought of as lacking the capacity to support high levels of social presence. Research and common experience show that learners are capable of both appropriating and extending media to overcome such limitations, notably in the development of emoticons and specialized lingo (Rourke, Anderson, Archer, \& Garrison, 1999).

\section{Transparency}

Transparency-in the sense of allowing individuals to observe, compare themselves with, and emulate others-is a feature of many social networking and Web 2.0 applications. For example, being able to observe the books purchased by others who have purchased a book in which you are interested provides important commercial and personal information to both consumers and online book retailers. Transparency in educational contexts has been elaborated on by Dalsgaard and Paulsen (2009), who argue that transparency, or "students' and teachers' insight into each other's activities and resources," is critically important to create conditions under which students will volunteer and can productively cooperate with others in learning activities. Transparency is a unique feature of social networking services and a component that has formerly been denied to distance education students, especially those distance students engaged in self-paced or continuous enrollment modes of DE. Transparency affords students insight into each other's actions, ideas, backgrounds, understanding, and contexts.

The potential of synchronous web conferencing systems and of social software to convey transparency and social presence may offer new avenues for student learning and support systems in distance education. In summary, we believe these tools hold strong theoretical promise to support interventions designed to improve learning, increase student engagement, and alleviate the high dropout rates traditionally observed in distance education.

\section{Collaboration}

Are distance students interested in collaborating with peers? While certain researchers show that some students are (Anderson, 2005; Caspi \& Gorki, 2006), others argue that distance education students are attached to the individual freedom and flexibility that the self-paced model affords. Indeed, flexibility is the main reason students choose distance courses (Poellhuber, 2005).

Cooperation between students is often analyzed in terms of cooperative or collaborative learning theories, which almost always assume a group production mode in which presence, common objectives, interdependence, peer interaction, and information sharing are essential components (Slavin, 1985). But some forms of peer collaboration are much more indirect and respect a desire for flexibility. For example, at the Norwegian Knowledge Institute, where collaboration is entirely voluntary but encouraged through a sophisticated social networking environment, $55 \%$ of self-paced distance education students choose to collaborate to some degree in their courses (Shaunessy, 2007). It is in this type of learnerdefined cooperation that we see the greatest potential for social networking in distance education. 


\section{Objectives}

We know little about the readiness or willingness of distance students to make effective use of these new technologies. (And as an aside, further research needs to be done to determine the institutional readiness of distance education or online educational institutions' readiness as well.) Consequently, researchers from four large Canadian distance education or blended learning institutions worked together to conduct a survey designed to describe the use of and interest in social software and Web 2.0 applications by distance education students and to measure their interest in collaborating with peers.

\section{Methodology}

We created a 90-item online questionnaire integrating four scales adapted from previously validated survey instruments. Each conceptual dimension integrated in the questionnaire had been the object of a literature review and previous publication. The proposed scales and items were validated by an expert distance education panel. We also gathered sociodemographic data and information pertaining to variables linked to persistence in distance education. The following scales were integrated: Cooperative and Learning Preferences (Owens \& Stratton, 1980); Tertiary Students' Readiness for Online Learning (TSROL) (Pillay, Irving, \& Tones, 2007); Social Software Expertise; and Interest in the Use of Social Software for Learning, DSSES (Poellhuber, 2007). The instrument was piloted with small groups of students (20-30) in both French and English.

A systematic sampling of students was applied in each of the four participating postsecondary institutions (three francophone [Université de Montréal, Cégep@distance, and TÉLUQ] and one anglophone [Athabasca University]). Between July of 2009 and February of 2010, an email and/or a written invitation to participate in the survey were sent to all students registering in a particular period of time, differing slightly in each institution. Typically a message was sent to all those enrolling in courses over a 1-2 month period.

We also had to adapt some of the language and the formulation of some of the items to the specific context of postsecondary distance education and to language issues.

\section{Scales}

In order to measure the predisposition of distance students toward collaboration versus individual learning, we adapted the Learning Preferences Scale for students from Owens and Stratton (1980) ( $\alpha=0.67$ and 0.76). In order to shorten the survey, we dropped the Competitive scale because it does not really apply to self-paced students.

Social software proficiency may very well depend upon general technical proficiency or attitudes toward technology. The literature review led us to choose the TSROL instrument (Pillay et al., 2007) because of its metric qualities, its positive correlation with other measurement instruments, and its relative shortness.

We also queried students on their perceptions of their expertise with and interest in using 
11 social software tools. Respondents had to answer a question concerning their experience with these tools based on a 5-point scale (no experience, beginner, intermediate, advanced, expert) and concerning their interest in having these tools used in their programming. Having an active account (though minimally used) was considered the cut-off point for the intermediate level of expertise.

\section{Sample Characteristics}

A total of 12,384 invitations were sent with a return of 3,462 completed questionnaires. This global return rate of $28 \%$ is comparable to return rates obtained in email-delivered surveys (Sheehan, 2001). It varied from 25.3\% at Cégep@distance to 47.3\% at Université de Montréal.

Women constituted $75.3 \%$ of the sample, reflecting the gender disproportion of the student population of all four institutions and long associated with distance education programming (Howell, Williams, \& Lindsay, 2003). Preliminary analysis showed that age is significantly related to many variables but not in a linear fashion. Table 1 shows that age was categorized in five categories of about 8-year spans, trying to match the "generations" hypothesis: 16-24 (Generation Z); 25-32 (Generation Y); 33-40 (Generation X2); 41-48 (Generation X1); 49 and over (Baby Boomers).

Table 1

Gender and Age Representation

\begin{tabular}{|l|c|c|}
\hline Gender/age & $N$ & Percent \\
\hline Male & 840 & 24.7 \\
\hline Female & 2554 & $75 \cdot 3$ \\
\hline Total & 3394 & 100 \\
\hline 16-24 years old & 1288 & 37.2 \\
\hline 25-32 years old & 941 & 27.2 \\
\hline 33-40 years old & 556 & 16.1 \\
\hline 41-48 years old & 362 & 10.5 \\
\hline 49 years old and over & 185 & $5 \cdot 3$ \\
\hline Total & 3332 & 100 \\
\hline
\end{tabular}

Globally, the Cégep@distance clientele is much younger than that of the three other institutions, which is not surprising because in the postsecondary system of Quebec, CÉGEP is an intermediate between secondary school and university. Université de Montréal's distance students are also younger than TÉLUQ's and Athabasca's.

Students from these four institutions also differ on some other variables. Overall, full-time 
study is the principal occupation of $42.5 \%$ of the sample, with work being the principal occupation of 50.6\%. But important and significant differences across institutions are also apparent, with Cégep@distance having more full-time students (71.6\%) than TÉLUQ (23.9\%) and Athabasca (30.9\%). While 38.5\% of the sample had no former experience in distance education, at Athabasca $65.2 \%$ of respondents had taken two or more distance courses previously, with $64.4 \%$ at TÉLUQ, but only $39.0 \%$ at Université de Montréal and 19.9\% at Cégep@distance having past experience with distance education studies. Furthermore, among students having previously taken distance courses, more students from Cégep@ distance than other institutions had previously failed at least one distance course $(33.9 \%$ versus $9.7 \%$ for students of other institutions).

\section{Quantitative Procedures}

Data from the four databases was cleansed and aggregated. Only valid questionnaires (unique and not empty) were retained. This left 3,462 answers corresponding to the criteria.

Exploratory factor analysis (principal components) was applied to the first 595 answers of the French questionnaire, and Cronbach alpha was calculated for each scale and subscale. The results led us to retain 8 of the 13 items of the Cooperative $(\alpha=.81)$ and Individual ( $\alpha$ $=.79$ ) preferences scales.

Two-way MANOVA and ANOVA tests were used on a variety of continuous measures as required conditions for this analysis being met (tested normal distribution, asymmetry, and skewness within the range accepted for normal distributions), permitting us to analyze an Age X Gender interaction effect.

For the categorical analysis, we used the Goodman-Kruskal Tau statistic and a column proportion post-hoc test. This test of association is based on a proportional reduction in error. It predicts the proportional increase of one categorical variable when knowing a second categorical variable (Cramer, 1994, p. 214).

\section{Results}

\section{Teamwork Experience}

Figure 1 shows that on the mean of a 5-point Likert Scale, 3 representing neither positive nor negative, past experience of teamwork was slightly more positive for males and for younger respondents. A two-way ANOVA yields an insignificant gender effect $\left(F_{(1,3304)}=\right.$ $2.28, p=.072)\left(n p^{2}=.001\right)$, but a significant age effect $\left(F_{(4,3304)}=6.42, p<.001\right)\left(n p^{2}=.011\right)$, as well as a significant interaction of age by gender effect $\left(F_{(4,3304)}=2.67, p=.005\right)\left(n p^{2}=\right.$ .005). For males, the relation between teamwork experience and age is almost linear, with

the 16-24 subgroup having the most positive teamwork experience. Figure 1 shows these effects graphically, crossing lines being characteristics of a significant interaction. 


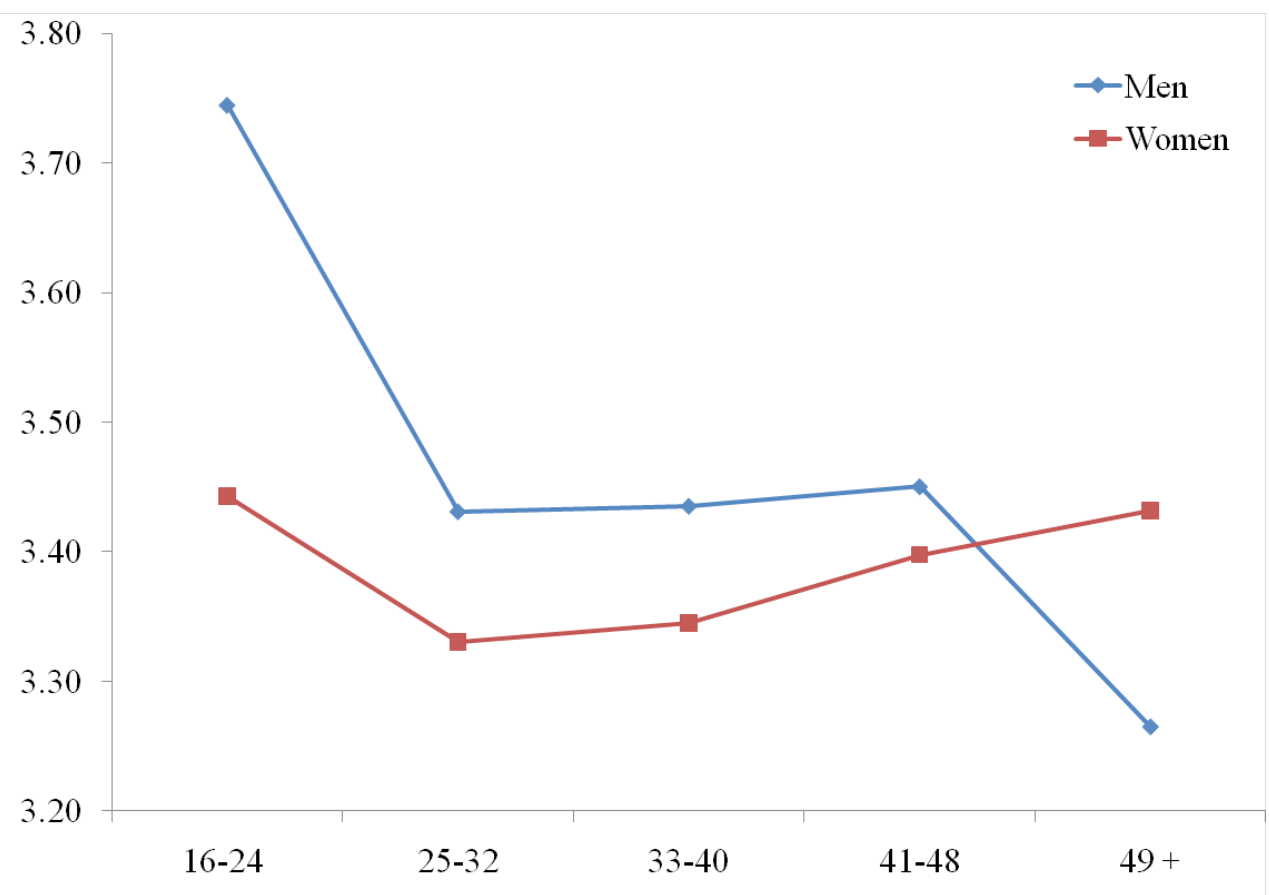

Figure 1. Mean evaluation of past experience with teamwork.

\section{Cooperative and Individual Preferences}

Cooperative preferences follow a pattern very similar to past experience with teamwork, suggesting that the two are related. This is confirmed by a correlation analysis leading to $r$ $=.614(p<$.001). Cooperative preferences are mildly but significantly higher for males than females $\left(F_{(1,3313)}=5.86, p<.001 ; n p^{2}=.005\right)$ and higher for younger than older $\left(F_{(4,3313)}=\right.$ $\left.1.18, p=.011 ; n p^{2}=.004\right)$, the largest differences being for the youngest (16-24) age group, the age by gender interaction effect being also mild but significant $\left(F_{(4,3313)}=1.13, p=.014\right.$; $n p^{2}=$.004). This gender effect is somewhat surprising, given both stereotypical beliefs and research evidence (Ocker, 2001) claiming that females enjoy collaborative learning opportunities more than males do. Individual preferences scored higher than cooperative preferences for every age group except the youngest (16-24). The 41-48 and over 49 groups distinguish themselves with much higher individual learning preferences.

\section{Interest in Collaborating with Peers}

Overall, $38.4 \%$ of respondents are interested or very interested in collaborating with peers in their distance courses. Here again, a two-way ANOVA leads to significant age $\left(F_{(4,3253)}=\right.$ $\left.2.80, p=.025 ; n p^{2}=.025\right)$ and gender effects $\left(F_{(1,3253)}=17.37, p<.001 ; n p^{2}=.005\right)$, as well as an age by gender interaction effect $\left(F_{(4,3253)}=0.36 . p=.841 ; n p^{2}=.000\right)$. These results are somewhat surprising given that the age effect is in the opposite direction to what was expected for those with past experiences with educational teamwork. Older distance students are more interested than younger students in collaborating with peers even though they have less experience with collaboration (Table 1). These results are true for both men and women. 


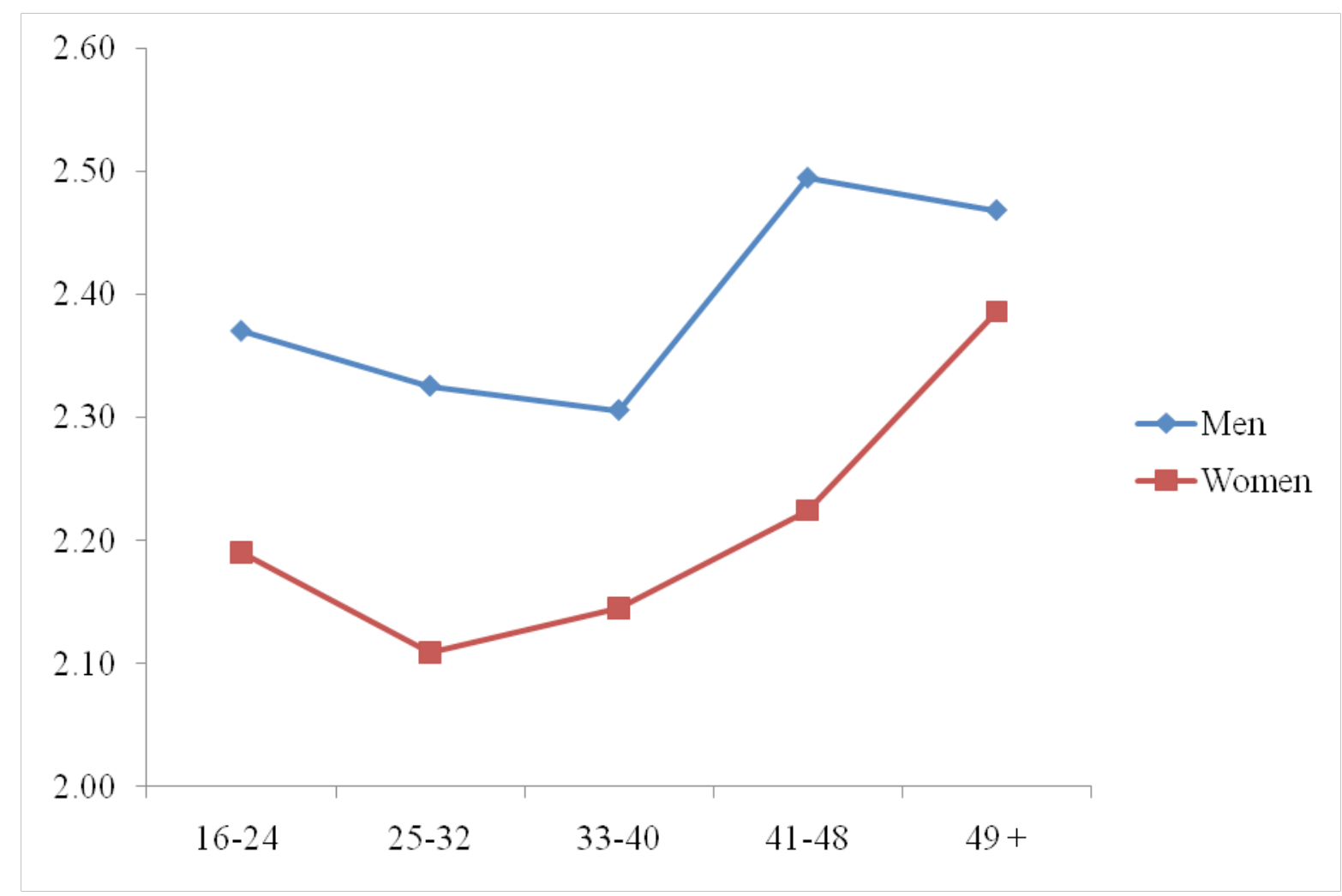

Figure 2. Mean interest in collaborating with peers in a distance course (5-point scale from $1=$ not at all interested to $5=$ very interested $)$.

Table 2 shows a significant and important institutional effect. Compared to other students, a larger proportion of Athabasca students are interested in collaborating with peers and a smaller proportion of students from TÉLUQ are interested in this form of collaboration. These differences across institutions hold true even when controlling for age and gender effects. 
Table 2

Interest in Collaboration with Peers by Institution

\begin{tabular}{llllll}
\hline & \multicolumn{2}{c}{ Athabasca } & Cégep@ & TÉLUQ & \multicolumn{2}{c}{$\begin{array}{c}\text { Université de } \\
\text { Montréal }\end{array}$} & Total \\
\cline { 2 - 5 } Not interested & $46.4 \%$ & $63.8 \%$ & $73.2 \%$ & $64.0 \%$ & $61.6 \%$ \\
\cline { 2 - 5 } Interested & $53.6 \%$ & $36.2 \%$ & $26.8 \%$ & $36.0 \%$ & $38.4 \%$ \\
\hline Taug $=.041 *(\mathrm{p}<.05)$ & & & & \\
\hline
\end{tabular}

Table 3

Correlations between Items Theoretically Related

\begin{tabular}{|c|c|c|c|c|}
\hline & $\begin{array}{l}\text { Teamwork expe- } \\
\text { rience }\end{array}$ & $\begin{array}{l}\text { Interest in col- } \\
\text { laboration }\end{array}$ & $\begin{array}{l}\text { Cooperative } \\
\text { preferences }\end{array}$ & $\begin{array}{l}\text { Individual } \\
\text { preferences }\end{array}$ \\
\hline Teamwork experience & 1 & & & \\
\hline Interest in collaboration & $.37^{* *}$ & 1 & & \\
\hline Cooperative preferences & $.61^{* *}$ & $.47^{* *}$ & 1 & \\
\hline Individual preferences & $-.42^{* *}$ & $-.47^{* *}$ & $-.53^{*}$ & 1 \\
\hline
\end{tabular}

Table 3 shows that the relationship between past teamwork experience and general cooperative preferences in learning is strong $(r=.614)$ and significant. While still significant, the relationship between a negative evaluation of past teamwork experience and individual learning preferences is weaker $(r=-.415)$.

\section{Tertiary Students' Readiness for Online Learning (TSROL)}

Table 4 shows significant differences between men and women of all ages for all TSROL scales. While the differences in attitudes toward technology are not large, those on the technical proficiency subscale are greater. Table 4 also shows an age difference on the three scales, with the younger (16-24 and 25-32) groups reporting higher scores on all three subscales. Although not very large numerically, this difference is consistent for men and women of all age groups. 
Table 4

TSROL Results for Age and Gender ANOVA

\begin{tabular}{|c|c|c|c|c|c|c|c|c|c|}
\hline & & $\begin{array}{l}16- \\
24\end{array}$ & $\begin{array}{l}25^{-} \\
32\end{array}$ & $\begin{array}{l}33^{-} \\
40\end{array}$ & $41-48$ & $49+$ & Age & Gender & $\begin{array}{l}\text { Age X } \\
\text { Gender }\end{array}$ \\
\hline \multirow{2}{*}{$\begin{array}{l}\text { Attitudes } \\
\text { toward tech- } \\
\text { nology }\end{array}$} & Men & 4.11 & 4.12 & 3.97 & 3.85 & 3.95 & \multirow[b]{2}{*}{$15 \cdot 36^{* * *}$} & \multirow[b]{2}{*}{$21.79 * * *$} & \multirow[b]{2}{*}{0.98} \\
\hline & Women & 4.03 & 3.93 & 3.84 & 3.60 & 3.77 & & & \\
\hline \multirow{2}{*}{$\begin{array}{l}\text { Technical } \\
\text { proficiency }\end{array}$} & Men & 4.24 & 4.29 & 4.18 & 4.06 & 3.96 & \multirow[b]{2}{*}{$15 \cdot 36^{* * *}$} & \multirow[b]{2}{*}{$136.03^{* * *}$} & \multirow{2}{*}{1.76} \\
\hline & Women & 3.88 & 3.73 & 3.66 & 3.49 & $3 \cdot 39$ & & & \\
\hline \multirow{2}{*}{$\begin{array}{l}\text { Competency } \\
\text { perception }\end{array}$} & Men & 4.45 & 4.52 & 4.41 & $4 \cdot 32$ & $4 \cdot 30$ & \multirow[b]{2}{*}{$13.03^{* * *}$} & \multirow{2}{*}{$57.00^{* * *}$} & \multirow{2}{*}{$2.95^{*}$} \\
\hline & Women & 4.36 & 4.28 & 4.17 & 4.01 & 3.99 & & & \\
\hline
\end{tabular}

${ }^{*} p<.05 \quad$ ** $p<.01 \quad * * * p<.001$

\section{Social Software Expertise}

Table 5 differentiates students with different levels of self-professed expertise in using various social media. This table presents the percentage of experienced users, sorted in ascending order. Notice that the social media for which distance education students' level of expertise is the highest are social networking, video sharing, photo sharing, and blogs. On the other hand, social bookmarking, 3D virtual worlds, electronic portfolios, Twitter, and web conferencing expertise remains low (with under $15 \%$ of users reaching at least the intermediate level). 
Table 5

Social Software Proficiency

\begin{tabular}{lll}
\hline $\begin{array}{l}\text { Proportion of intermediate, advanced and expert } \\
\text { users }\end{array}$ & $n$ & $\%$ \\
\hline Social bookmarking & 212 & $6.1 \%$ \\
3D virtual worlds & 224 & $6.5 \%$ \\
Electronic portfolios & 415 & $12.2 \%$ \\
Twitter & 438 & $12.7 \%$ \\
Web conferencing & 473 & $13.8 \%$ \\
Podcasts & 511 & $14.8 \%$ \\
Wikis & 625 & $18.3 \%$ \\
Blogs & 875 & $25.4 \%$ \\
Photo sharing & 1150 & $33.7 \%$ \\
Video sharing & 1811 & $52.9 \%$ \\
Social networking & 2380 & $69.5 \%$ \\
\hline
\end{tabular}

Table 6 synthesizes the results of a series of two-way ANOVA tests crossing the mean expertise level for a given social media with gender and age. The $F$ statistic is presented along with its significance level.

Table 6

Self-Professed Expertise with Social Software by Age and Gender

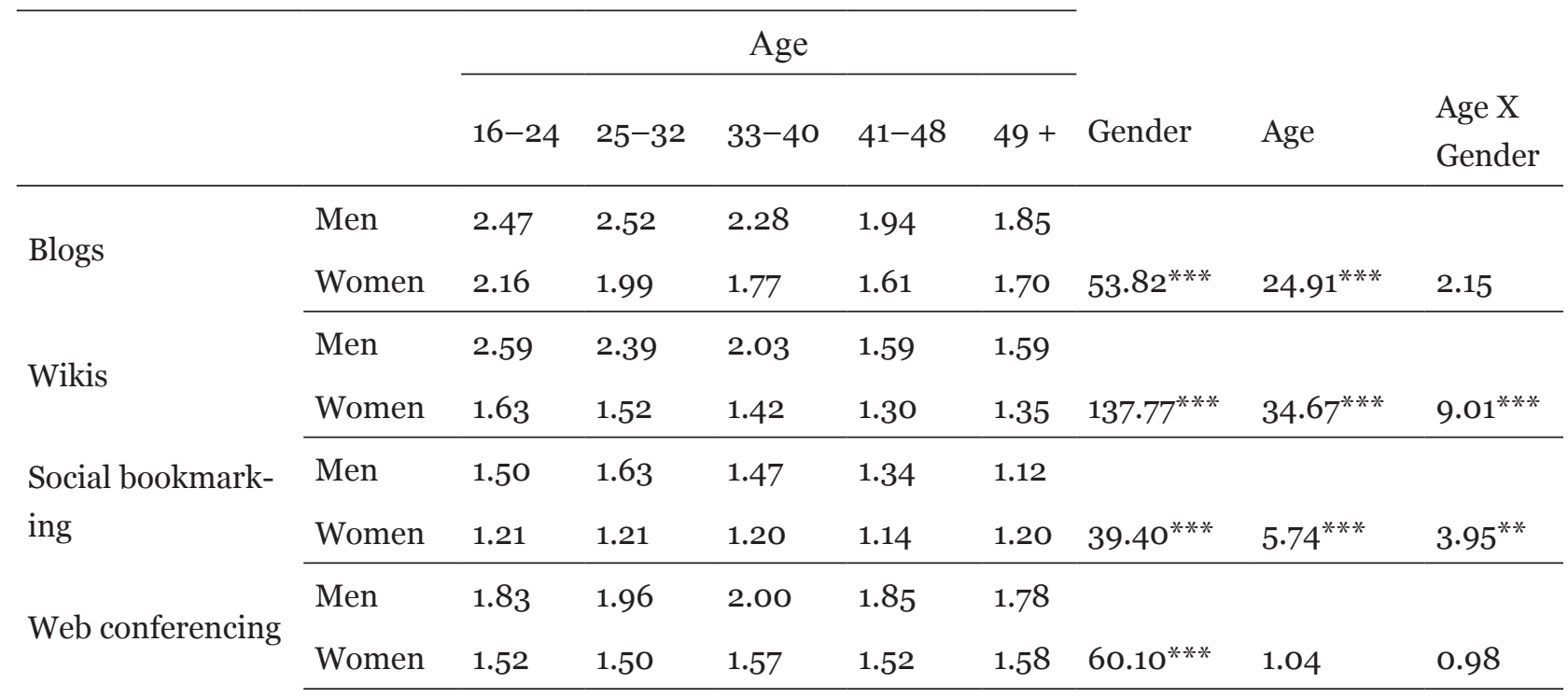




\begin{tabular}{|c|c|c|c|c|c|c|c|c|c|}
\hline \multirow{2}{*}{ Social networking } & Men & 3.71 & 3.45 & 2.98 & 2.44 & 2.08 & & & \\
\hline & Women & $3 \cdot 71$ & $3 \cdot 37$ & 2.71 & 2.22 & 2.11 & $3.99^{* * *}$ & $132.79^{* * *}$ & 1.01 \\
\hline \multirow{2}{*}{ Photo sharing } & Men & 2.42 & 2.67 & 2.33 & 1.97 & 1.76 & & & \\
\hline & Women & 2.25 & 2.21 & 2.04 & 1.75 & 1.58 & $19.44^{* * *}$ & $20.05^{* * *}$ & 1.08 \\
\hline \multirow{2}{*}{ Video sharing } & Men & 3.55 & 3.28 & 2.69 & 2.36 & 2.08 & & & \\
\hline & Women & 3.11 & 2.67 & 2.26 & 1.95 & 1.79 & $55.75^{* * *}$ & $97.42^{* * *}$ & 1.02 \\
\hline \multirow{2}{*}{ Podcasts } & Men & 2.06 & 2.23 & 1.98 & 1.62 & 1.58 & & & \\
\hline & Women & 1.46 & 1.52 & 1.42 & 1.33 & 1.33 & $105.63^{* * *}$ & $12.15^{* * *}$ & $3.17^{*}$ \\
\hline \multirow{2}{*}{ Twitter } & Men & 1.86 & 1.96 & 1.78 & 1.56 & 1.50 & & & \\
\hline & Women & 1.56 & 1.58 & 1.47 & 1.35 & 1.36 & $32.74^{* * *}$ & $8.67^{* * *}$ & 0.71 \\
\hline \multirow{2}{*}{ 3D virtual worlds } & Men & 1.65 & 1.66 & 1.35 & 1.34 & 1.30 & & & \\
\hline & Women & 1.24 & 1.24 & 1.19 & 1.14 & 1.12 & $63.69^{* * *}$ & $11.12^{* * *}$ & $4.05^{* *}$ \\
\hline \multirow{2}{*}{$\begin{array}{l}\text { Electronic port- } \\
\text { folios }\end{array}$} & Men & 1.97 & 1.81 & 1.56 & 1.45 & 1.20 & & & \\
\hline & Women & 1.54 & 1.35 & 1.33 & 1.24 & 1.21 & $38.04^{* * *}$ & $24.33^{* * *}$ & $3.69^{* *}$ \\
\hline
\end{tabular}

Table 6 shows that there are systematic gender and age differences for nearly all social software, with men and younger respondents reporting higher levels. Men reported higher expertise levels for every social software than women did. The younger (16-24 and 25-32) groups reported higher expertise with nearly all social media except web conferencing.

\section{Interest in Using Social Software for Learning Purposes}

Table 7 presents the proportion of respondents who are interested or very interested in integrating social software into their learning experience. The list is ordered by the percentage of interested respondents. This table reveals the same tendencies as the previous one, demonstrating higher interest for using social software that is most familiar to respondents. This being said, web conferencing is the exception: $42.6 \%$ of respondents are interested in using it, whereas only $13.8 \%$ of them have any significant experience using the software. 
Table 7

Interest in Using Social Software for Learning Purposes

\begin{tabular}{lll}
\hline Proportion of interested or very interested users & $n$ & \% \\
\hline Social bookmarking & 616 & $18.1 \%$ \\
Twitter & 627 & $18.5 \%$ \\
3D virtual worlds & 473 & $19.4 \%$ \\
Electronic portfolios & 965 & $28.5 \%$ \\
Wikis & 1066 & $31.3 \%$ \\
Podcasts & 1143 & $33.7 \%$ \\
Photo sharing & 1237 & $36.4 \%$ \\
Blogs & 1368 & $40.2 \%$ \\
Web conferencing & 1449 & $42.6 \%$ \\
Social networking & 1797 & $52.8 \%$ \\
Video sharing & 1976 & $58.2 \%$ \\
\hline
\end{tabular}

\section{Age and Gender Effects on Experience and Interest}

Table 8 presents the results of a series of two-way ANOVAs crossing interest in using social software in courses with gender and age where scores indicate more interest. It shows systematic gender differences, with men being more interested than women in the use of social software for learning purposes. This is true of every social media except social networking. Age differences are also systematically present but not always in favour of the younger groups. 
Table 8

Interest in Using Social Software to Learn by Age and Gender

\begin{tabular}{|c|c|c|c|c|c|c|c|c|c|}
\hline & & \multicolumn{5}{|c|}{ Age } & \multirow[b]{2}{*}{ Age } & \multirow[b]{2}{*}{ Gender } & \multirow[b]{2}{*}{$\begin{array}{l}\text { Age X Gen- } \\
\text { der }\end{array}$} \\
\hline & & $16-24$ & $25-32$ & $33-40$ & $41-48$ & $49+$ & & & \\
\hline \multirow{2}{*}{ Blogs } & Men & 2.26 & 2.50 & 2.28 & 2.31 & 2.53 & & & \\
\hline & Women & 2.11 & 2.22 & 2.22 & 2.08 & 2.31 & $5.82^{*}$ & $23.40^{*}$ & .70 \\
\hline \multirow{2}{*}{ Wikis } & Men & 2.60 & 2.75 & 2.51 & 2.32 & 2.33 & & & \\
\hline & Women & 1.96 & 2.01 & 2.04 & 1.87 & 2.03 & $3 \cdot 36^{*}$ & $81.45^{*}$ & 1.85 \\
\hline \multirow{2}{*}{$\begin{array}{l}\text { Social book- } \\
\text { marking }\end{array}$} & Men & 1.78 & 2.09 & 2.02 & 1.99 & 2.07 & & & \\
\hline & Women & 1.60 & 1.82 & 1.86 & 1.73 & 2.01 & $10.07^{*}$ & $14.08^{*}$ & .56 \\
\hline \multirow{2}{*}{$\begin{array}{l}\text { Web confer- } \\
\text { encing }\end{array}$} & Men & 2.30 & 2.65 & 2.72 & 2.70 & 2.72 & & & \\
\hline & Women & 2.07 & 2.34 & 2.41 & 2.37 & 2.46 & $15.65^{*}$ & $27.63^{*}$ & 0.26 \\
\hline \multirow{2}{*}{$\begin{array}{l}\text { Social net- } \\
\text { working }\end{array}$} & Men & 2.69 & 2.55 & 2.43 & 2.25 & 2.40 & & & \\
\hline & Women & 2.75 & 2.60 & 2.37 & 2.11 & 2.23 & $18.15^{*}$ & 1.00 & .89 \\
\hline \multirow{2}{*}{$\begin{array}{l}\text { Photo shar- } \\
\text { ing }\end{array}$} & Men & 2.18 & 2.38 & 2.38 & 2.23 & 2.30 & & & \\
\hline & Women & 2.17 & 2.21 & 2.22 & 1.09 & 2.16 & $2.08^{*}$ & $5.05^{*}$ & .73 \\
\hline \multirow{2}{*}{$\begin{array}{l}\text { Video shar- } \\
\text { ing }\end{array}$} & Men & 2.98 & 2.96 & 2.67 & 2.57 & 2.57 & & & \\
\hline & Women & 2.71 & 2.54 & 2.54 & 2.33 & 2.45 & $11.57^{*}$ & $21.74^{*}$ & 1.57 \\
\hline \multirow{2}{*}{ Podcasts } & Men & 2.27 & 2.64 & 2.54 & 2.44 & 2.55 & & & \\
\hline & Women & 1.90 & 2.13 & 2.22 & 2.04 & 2.09 & $8.95^{*}$ & $52.37^{*}$ & .59 \\
\hline \multirow{2}{*}{ Twitter } & Men & 1.80 & 1.93 & 1.91 & 1.95 & 2.05 & & & \\
\hline & Women & 1.65 & 1.72 & 1.80 & 1.66 & 1.83 & $2.70^{*}$ & $15.87^{*}$ & .46 \\
\hline \multirow{2}{*}{$\begin{array}{l}\text { 3D virtual } \\
\text { worlds }\end{array}$} & Men & 1.69 & 1.90 & 1.82 & 1.73 & 2.04 & & & \\
\hline & Women & 1.58 & 1.86 & 1.92 & 1.73 & 1.98 & $6.62^{*}$ & $0.09^{*}$ & .55 \\
\hline \multirow{2}{*}{$\begin{array}{l}\text { Electronic } \\
\text { portfolios }\end{array}$} & Men & 2.04 & 2.26 & 2.22 & 2.20 & 2.03 & & & \\
\hline & Women & 1.97 & 2.06 & 2.11 & 1.96 & 1.99 & $5 \cdot 28^{*}$ & $5.28^{*}$ & .53 \\
\hline
\end{tabular}

${ }^{*} p<.05,{ }^{* *} p<.01,{ }^{* * *} p<.001$

Table 9 presents the percentage of respondents in each age group who are interested or very interested in the use of social media to learn, along with the post-hoc proportion test, which makes it easier to interpret age-group differences. This table makes it evident that for many types of social software, the oldest $(49+)$ age group is more interested in learning use than the younger 16-24 group and/or the 25-32 group. This is true of social bookmarking, Twitter, 3D virtual worlds, podcasts, blogs, and web conferencing. For the other social 
software, differences are in favour of the younger groups, but it should be noted that among the younger groups, the proportion of those interested in learning uses of social networking and video sharing is lower than the proportion of users reporting at least an intermediate level of expertise, while for older age groups it is the reverse situation.

Table 9

Interest in Using Social Software for Learning Purposes

\begin{tabular}{|c|c|c|c|c|c|c|c|}
\hline & $16-24$ & $25-32$ & $33-40$ & $41-48$ & $49+$ & tau & $p$ \\
\hline $\begin{array}{l}\text { Social book- } \\
\text { marking }\end{array}$ & $13.3 \%^{a}$ & $20.6 \%^{b}$ & $21.1 \%^{\mathrm{b}}$ & $17.4 \%{ }^{\mathrm{a}, \mathrm{b}}$ & $25.0 \%^{\mathrm{b}}$ & .01 & $<.001$ \\
\hline Twitter & $16.5 \%^{\mathrm{a}}$ & $18.4 \%^{\mathrm{a}}$ & $20.7 \%^{a}$ & $17.7 \%^{a}$ & $24.4 \%^{\mathrm{a}}$ & .00 & .06 \\
\hline $\begin{array}{l}\text { 3D virtual } \\
\text { worlds }\end{array}$ & $15.1 \%^{\mathrm{a}}$ & $21.7 \%^{b}$ & $25.5 \%^{\mathrm{b}}$ & $18.8 \%{ }^{\mathrm{a}, \mathrm{b}}$ & $26.9 \%^{b}$ & .01 & $<.001$ \\
\hline $\begin{array}{l}\text { Electronic } \\
\text { portfolios }\end{array}$ & $26.8 \%^{a}$ & $29.3 \%^{a}$ & $31.2 \%^{\mathrm{a}}$ & $28.7 \%^{a}$ & $24.4 \%^{a}$ & .00 & .14 \\
\hline Wikis & $33.0 \%^{a}$ & $31.7 \% \%^{a, b}$ & $31.8 \%{ }^{\mathrm{a}, \mathrm{b}}$ & $24.7 \%^{\mathrm{b}}$ & $28.9 \% \%^{a, b}$ & .00 & .10 \\
\hline Podcasts & $28.3 \%^{a}$ & $37.1 \%^{\mathrm{b}}$ & $37.2 \%^{b}$ & $35.0 \% \%^{\mathrm{a}, \mathrm{b}}$ & $31.7 \%$ a,b & .00 & $<.001$ \\
\hline Photo sharing & $35.7 \%^{a}$ & $37.7 \%^{a}$ & $38.1 \%^{a}$ & $34.1 \%^{a}$ & $33.0 \%^{a}$ & .00 & .52 \\
\hline Blogs & $36.8 \%^{a}$ & $42.6 \%^{a}$ & $43.8 \%^{\mathrm{a}}$ & $36.1 \%^{a}$ & $44.4 \%^{\mathrm{a}}$ & .01 & $<.001$ \\
\hline $\begin{array}{l}\text { Web confer- } \\
\text { encing }\end{array}$ & $34.0 \%^{\mathrm{a}}$ & $45.2 \%^{\mathrm{b}}$ & $50.4 \%^{\mathrm{b}}$ & $49.2 \%^{b}$ & $50.3 \%^{b}$ & .01 & $<.001$ \\
\hline $\begin{array}{l}\text { Social net- } \\
\text { working }\end{array}$ & $61.2 \%^{\mathrm{a}}$ & $55.2 \%^{\mathrm{b}}$ & $44.4 \%^{\mathrm{c}}$ & $37.0 \%^{c}$ & $41.4 \%^{c}$ & .03 & $<.001$ \\
\hline Video sharing & $64.0 \%{ }^{a}$ & $57.2 \%^{\mathrm{b}}$ & $56.0 \%$ b,c & $48.2 \%^{c}$ & $48.9 \%$ b,c & .01 & $<.001$ \\
\hline \multicolumn{8}{|c|}{$\begin{array}{l}{ }^{*} p<.05 \text { (column proportion test); Each column pair in Table } 9 \text { is compared with a } \mathrm{z} \text { test. If two columns differ significantly, } \\
\text { a different superscript letter is assigned. Hence, if two columns have the same superscript letter, they do not differ from each } \\
\text { other, and if they have different superscript letters, they differ significantly from each other at the .o5 level. }\end{array}$} \\
\hline $\begin{array}{l}\text { It is interesting } \\
\text { media, they exp } \\
\text { than younger st } \\
\text { the value of the } \\
\text { have expectatio } \\
\text { students points } \\
\text { begin using thes }\end{array}$ & $\begin{array}{l}\text { note that } \\
\text { s equal or } \\
\text { ents do. Tl } \\
\text { tools for } \mathrm{f} \\
\text { of only inf } \\
\text { the potent } \\
\text { ools in the }\end{array}$ & $\begin{array}{l}\text { hile older s } \\
\text { igher level } \\
\text { s could sug } \\
\text { mal learni } \\
\text { mal and en } \\
\text { l for broad } \\
\text { programm }\end{array}$ & $\begin{array}{l}\text { lents profes } \\
\text { interest in } \\
\text { t that thos } \\
\text { or that they } \\
\text { tainment u } \\
\text { d enthusias }\end{array}$ & $\begin{array}{l}\text { less experti } \\
\text { ing these } \mathrm{m} \\
\text { vith more e } \\
\text { ave becom } \\
\text { However, } \\
\text { adoption i }\end{array}$ & $\begin{array}{l}\text { with all the } \\
\text { lia in their } \\
\text { erience do } \\
\text { ccustomed } \\
\text { e interest b } \\
\text { istitutions }\end{array}$ & $\begin{array}{l}\text { ocial } \\
\text { idies } \\
\text { t see } \\
\text { and } \\
\text { older } \\
\text { re to }\end{array}$ & \\
\hline
\end{tabular}




\section{Discussion}

Though not discussed in great detail in this report, the differences between men and women are important and significant, pertaining to a wide variety of indicators, specifically when it comes to attitudes about and experience with technology. Men claimed to be more experienced and to have more expertise than women did in regards to all social software, except social networking. These results hardly come as a surprise when one considers the numerous studies that reveal these differences, such as the tendency of men to demonstrate a feeling of competence and a favourable attitude toward the use of technology. For example, men consider themselves more competent in using the Internet than women do (Miller, Schweingruber, \& Brandenburg, 2000), and other studies also mention that men report a higher level of self-confidence with technology (Whitley, 1997; Jackson, Ervin, Gardner, \& Schmitt, 2001). These findings might be attributed to the self-report methodology as some research findings question the validity of claims regarding any actual differences between men and women concerning their expertise with technology (He \& Freeman, 2009).

Surprisingly, men recorded more positive experiences with teamwork than women did, as well as higher cooperative preferences for learning. For men, teamwork experience ratings changed almost linearly with age. As age increased, teamwork experience ratings decreased. One can perhaps assume that the impact of pedagogical renewal efforts in Quebec and elsewhere over the past few years has provided the younger groups of students with an academic setting that is more focused on teamwork. Though women are traditionally perceived as being more interested in cooperation than men are, these results demonstrate that men of all ages are more interested in cooperating with peers in the context of distance education courses. This does not necessarily represent an interest in teamwork because social software allows new pedagogies (Anderson \& Dron, 2011) and forms of networked collaboration and cooperation, many of which are indirect, such as tracing history and rating artifacts. These are the more popular social software applications (social networking, video sharing, photo sharing, i.e., the ones in which we find the largest proportion of experienced users).

Table 3 demonstrates that the correlation between more or less positive experiences with teamwork, interest in collaboration, cooperative preferences, and individual preferences flows in the expected direction. That being said, if the correlation between experience in teamwork and cooperative preferences is strong $(r=.614)$, it is much weaker in regards to interest in collaboration in the context of distance courses $(r=.372)$. For older respondents, interest in collaboration with peers in a distance course is higher than for younger respondents, in spite of less positive teamwork experience and lower cooperative preferences. Perhaps older students place higher value on opportunities for interaction at a distance than younger students do.

The Learning Preferences scale measures preferences for learning situations in general, and respondents likely associate it specifically with learning experienced in classroom contexts. It is possible that in distance education contexts, these preferences change and that certain people who generally lean toward more cooperative preferences are not necessarily inter- 
ested in collaborating with their peers. In fact, this type of cooperation implies a compromise in regards to the flexibility of distance learning (increased collaboration implies loss of individual freedom necessitated by synchronizing pace and time scheduling), the flexibility of the course being the main reason for choosing this type of learning (Poellhuber, 2005). Older students seem to be more ready than younger students to compromise this flexibility. A large proportion of students (over half at Cégep@distance) are simultaneously registered in a campus program at another on-campus institution. The interest in collaboration might be explained by the fact that the students registered in distance institution programs have more desire for interaction than on-campus students who have a greater opportunity for informal contact with peers.

Interest in collaborating with peers varies strongly according to the institution from which the data was collected. Students at Athabasca are much more interested than others in collaborating with peers. These differences remain true despite age and gender controls. This suggests that there may be important cultural, institutional, or linguistic effects present. In terms of institutional characteristics, Athabasca more closely resembles TÉLUQ on a number of variables (e.g., student age, experience with distance education), and yet there are large differences in interest in collaborating with peers. These broader effects remain an interesting area for further research.

The differences in terms of expertise or attitudes toward technology are systematically significant once they are broken down according to age. The 16-24-year-old group distinguishes itself on almost every indicator. This supports the "hypothesis" about Generation Z being the so-called "Net Generation," which is somewhat controversial in the literature (Bullen, Morgan, Belfer, \& Qayyum, 2009). However, these significant differences among the 16-24-year-old group do not necessarily signify a homogeneous group, and, in our experience, there are very large differences in technological proficiency, interest, and experience within each age group.

It is worthy of note that, generally, the percentage of respondents interested in using social networking tools for learning surpasses the proportion of users experienced in the use of these tools. The list of social media, by proportional order of most experienced users, is as follows: social networking, video-sharing sites, photo-sharing sites, and blogs. Social media that users are most interested in using as learning tools are almost identical to the list of experience (video sharing, social networking, blogs). Despite the anomaly of web conferencing (very few respondents are experienced in the use of this technology [13.8\%], yet most are interested), it seems that the more one is exposed to a technology, the more interest there is in seeing its use in formal courses.

Although the effect of gender was as predicted (interest in using social media is higher for men than for women), the effect of age, which is significant in almost every social medium, does not follow previously noted tendencies. In fact, in this respect, the 16-24-year-old group distinguishes itself from other age groups not by revealing an increased desire of use, but rather a decreased one. In other words, older students seem to see the pedagogical potential of social media more than younger ones do, even if the older ones are less experi- 
enced in using these types of media. This is possibly explained by the fact that young people use social media for social and entertainment purposes and do not necessarily see them as tools for learning. This seems to be particularly true for social networking, which a fairly large number of experienced users are not interested in using for learning purposes. On the other hand, older students are typically the ones who have more experience in distance learning but are also the ones who are registered in the institutions' programs rather than visiting students. They seem to understand the potential that these tools offer or, at least, are more interested in using them for learning.

The sharing of bookmarks and microblogs appeared last on the list of Internet use and experience. Given the rise in popularity of Twitter over the past two years, this may not be representative of the current situation in 2011 (the data for this study having been gathered between July of 2009 and February of 2010).

\section{Conclusion}

Our findings show that a significant portion of distance students are interested in collaborating with peers, but that there is also a significant proportion of self-paced distance education students who are not. This interest in peer collaboration varies with age, gender, and institutions. Compared to women and older students, men and younger respondents claim to have more positive experiences related to teamwork as well as stronger cooperative preferences. Interest in collaborating with peers in a distance course increases with age. A similar phenomenon is observed in interest in the use of social software for learning purposes. While being less experienced than their younger colleagues, older students show more interest in learning with social software.

Strong and significant differences are observed on a variety of indicators in favour of males and younger respondents. This gives some support to the Net Generation hypothesis.

The social software in which we find the largest proportion of experienced users (and which are probably the easiest to implement and use in distance education) are the ones that require only minimal participation: video-sharing sites, photo-sharing sites, and the very common social networking sites. Web conferencing is a noteworthy exception. Even though it is one of the least-known social software applications, it is the one that students are the most interested in using to learn. Of course, the extremely rapid increase in the use of Skype web conferencing may be changing these experience and expertise levels today.

An important institutional effect has been observed regarding interest in collaborating with peers. It is not clear whether this effect is linked to the institutional culture, anglophone and francophone culture, linguistic differences, or other variables.

While the number of respondents was quite large and the return rate acceptable, the methodology used has some limits. As the survey was only presented online, there is a selfselection effect that may have excluded students with limited or no Internet access and/or with very minimal technology skills. While the sample was systematic, a history effect (an 
effect linked to events external to the study during a particular timeframe) may be linked to the fact that the questionnaire distribution was confined to 4-5-week periods in 2009. This is particularly true for Cégep@distance, where the survey was conducted with summer students. Finally, it must be noted that most scales used in the questionnaire measure perceptions rather than actual performance or skill.

Future research should focus on understanding the determinants of the interest toward collaboration and/or using social software as learning tools. We also need further elaboration of models and development of interventions that allow and help interested students to collaborate directly or indirectly with peers or tutors, while preserving their individual preferences. 


\section{References}

Alexa (2011). Top sites. Retrieved Sept 6, 2011 from http://www.alexa.com/topsites/global

Allen, E., \& Seaman, J. (2010). Class differences: Online education in the United States, 2010. Retrieved from http://sloanconsortium.org/publications/survey/class differences

Anderson, T. (2005). Distance learning: Social software's killer app? Paper presented at the ODLAA 2005 Conference, Adelaide, Australia. Retrieved from http://citeseerx. ist.psu.edu/viewdoc/download?doi=10.1.1.95.630\&rep=rep1\&type=pdf

Anderson, T., \& Dron, J. (2011). Three generations of distance education pedagogy. International Review of Research on Distance and Open Learning, 12(3), 80-97. Retrieved from http://www.irrodl.org/index.php/irrodl/article/view/890/1826

Bean, J., \& Metzner, B. (1985). A conceptual model of nontraditional undergraduate student attrition. Review of Educational Research, 55(4), 485-540.

Bernard, R. M., Abrami, P. C., Lou, Y., Borokhovski, E., Wade, A., Wozney, L., et al. (2004). How does distance education compare with classroom instruction? A meta-analysis of the empirical literature. Review of Educational Research, 74(3), 379-439.

Bourdages, L., \& Delmotte, C. (2001). La persistance aux études universitaires à distance. Journal of Distance Education/Revue de l'enseignement à distance, 16(2), 23-36.

Bruns, A. (2008). Blogs, Wikipedia, Second Life, and beyond: From production to produsage. New York: Lang.

Bullen, M., Morgan, T., Belfer, K., \& Qayyum, A. (2009). The Net generation in higher education: Rhetoric and reality. International Journal of Excellence in E-Learning, 2, $1-13$.

Caspi, A., \& Gorsky, P. (2006). Distance education students' dialogic behavior. Studies in Higher Education, 31(6), 735-752.

Cramer, D. (1994). Introducing statistics for social research: Step-by-step calculations and computer techniques using SPSS. London: Routledge.

Daft, R., \& Lengel, R. (1986). Organizational information requirements, media richness and structural determinants. Management Science, 32(5), 554-571.

Dalsgaard, C., \& Paulsen, M. (2009). Transparency in cooperative online education. International Review of Research in Open and Distance Learning, 1O(3). Retrieved from http://www.irrodl.org/index.php/irrodl/article/view/671/1267 
Dron, J. (2010). Self-organization in social software for learning. In S. Dasgupta (Ed.), Social computing: Concepts, methodologies, tools, and applications (pp. 312-320). Hershey, NY: IGI Global.

Dron, J., \& Anderson, T. (2007). Collectives, networks and groups in social software for elearning. In T. Bastiaens \& S. Carliner (Eds.), Proceedings of World Conference on E-Learning in Corporate, Government, Healthcare, and Higher Education 2007 (pp. 2460-2467). Chesapeake, VA: AACE. Retrieved from www.editlib.org/index. cfm/files/paper 26726.pdf

Dron, J., \& Anderson, T. (2009). How the crowd can teach. In S. Hatzipanagos \& S. Warburton (Eds.), Handbook of research on social software and developing community ontologies (pp.1-17). Hershey, PA: IGI Global.

Facebook (2011). Statistics. Retrieved Sept 6, 2011 from http://www.facebook.com/press/ info.php?statistics

Gagné, P., Deschênes, A.-J., Bourdages, L., Bilodeau, H., \& Dallaire, S. (2002). Les activités d'apprentissage et d'encadrement dans des cours universitaires à distance: Le point de vue des apprenants. Journal of Distance Education/Revue de l'enseignement à distance, $17(1), 25-56$.

Garrett, N., Thoms, B., Soffer, M., \& Ryan, T. (2007). Extending the Elgg social networking system to enhance the campus conversation. Claremont, CA: Claremont Graduate University. Retrieved from http://conversation.cgu.edu/sl2/files/125/622/ ExtendingElgg.pdf

He, J., \& Freeman, L. (2009). Are men more technology-oriented than women? Paper presented at the Americas' Conference on Information Systems (AMCIS) 2009. Retrieved from http://aisel.aisnet.org/amcis2009/672

Howell, S., Williams, P., \& Lindsay, N. (2003). Thirty-two trends affecting distance education: An informed foundation for strategic planning. Online Journal of Distance Education Administration, 6(3). Retrieved from http://www.westga. edu/ distance/ojdla/fall63/howell63.html

Jackson, L. A., Ervin, K. S., Gardner, P. D., \& Schmitt, N. (2001). Gender and the Internet: Women communicating and men searching. Sex Roles: A Journal of Research, 44(5/6), 363-379.

Jones, N., \& Thomas, P. (2007). Inter-organizational collaboration and partnerships in health and social care: The role of social software. Public Policy and Administration, 22(3), 289-302. 
Miller, L., Schweingruber, H., \& Brandenburg, C. (2000). Technology acculturation among adolescents: The school and home environments. In J. Bourdeau \& R. Heller (Eds.), Proceedings of World Conference on Educational Multimedia, Hypermedia and Telecommunications 2000 (pp. 1694-1695). Chesapeake, VA: AACE.

Misko, J. (2000). Getting to grips with self-paced learning. Leabrook, Australia: National Centre for Vocational Education Research. Retrieved from http://www.ncver.edu. au/publications/410.html

Misko, J. (2001). Different modes of delivery: Does increased flexibility lead to better student outcomes? Australasian Association for Institutional Research, 10(1). Retrieved from http://www.aair.org.au/jir/Mayo1/Misko.pdf

Ocker, R. J. (2001). Collaborative learning environments: Exploring student attitudes and satisfaction in face-to-face and asynchronous computer conferencing settings. Journal of Interactive Learning Research, 12(4), 427.

Owens, L., \& Stratton, R. G. (1980). The development of a cooperative, competitive, and individualised learning preference scale for students. British Journal of Educational Psychology, 50, 147-161.

Pillay, H., Irving, K., \& Tones, M. (2007). Validation of the diagnostic tool for assessing tertiary students' readiness for online learning. Higher Education Research \& Development, 26(2), 217-234. doi: 10.1080/07294360701310821

Poellhuber, B. (2005). L'univers mouvant des FOAD: Quels intérêts et quels enjeu? Conference given at Laval University. Retrieved from http://www.heurepedagogique. ulaval.ca/lib php/video.asp?idVideo=112\&type $=0$

Poellhuber, B. (2007). Les effets de l'encadrement et de la collaboration sur la motivation et la persévérance dans les formations ouvertes et à distances soutenues par les TIC (Doctoral thesis). Montreal, QC: Université de Montréal.

Richardson, W. (2006). Blogs, wikis, podcasts and other powerful web tools for classrooms. Thousand Oaks, CA: Corwin Press.

Rourke, L., Anderson, T., Archer, W., \& Garrison, D. R. (1999). Assessing social presence in asynchronous, text-based computer conferences. Journal of Distance Education/ Revue de l'enseignement à distance, 14(3), 51-70.

Rovai, A. (2003). In search of higher persistence rates in distance education online programs. Internet in Higher Education, 6(1), 1-16.

Shaunessy, M. (2007). An interview with Morten Flate Paulsen: Focusing on his theory of cooperative freedom in online education. EdNews, April 26, 2007. Retrieved from http://www.ednews.org/articles/10626/1/An-Interview-with-Morten-Flate- 
Paulsen-Focusing-on-His-Theory-of-Cooperative-Freedom-in-Online-Education/ Page1.html

Sheehan, K. B. (2001). Email survey response rates: A review. Journal of Computer Mediated Communications, 6(2). Retrieved from http://jcmc.indiana.edu/vol6/is$\underline{\text { sue2/sheehan.html. }}$

Short, J., Williams, E., \& Christie, B. (1976). The social psychology of telecommunications. New York: Wiley.

Slavin, R. E. (1985). Cooperative learning: Student teams. Washington, D.C.: National Educational Association.

Smith, S., Salaway, S., \& Caruso, J. B. (2009). The ECAR study of undergraduate students and information technology, 2009 (Research Study, Vol. 6). Boulder, CO: EDUCAUSE Center for Applied Research. Retrieved from http://www.educause.edu/ ecar

Sweet, R. (1986). Applying Tinto's model of student dropout to distance education. Distance Education, 7(2), 201-213.

Tinto, V. (1975). Dropout from higher education: A theoretical synthesis of recent research. Review of Educational Research, 45(1), 89-125.

Whitley, B. E. (1997). Gender differences in computer-related attitudes and behavior: A meta-analysis. Computers in Human Behavior, 13(1), 1-22.

Woodley, A. (2004). Conceptualizing student dropout in part-time distance education: Pathologizing the normal. Open Learning, 19(1), 47-63.

\section{Athabasca University $\mathbf{I}$}

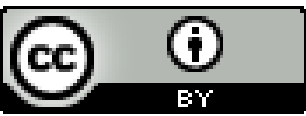

